\author{
Karolina Janeczko \\ http://orcid.org/0000-0001-7815-9183 \\ Uniwersytet Papieski Jana Pawła II w Krakowie \\ ctacaroola@gmail.com
}

DOI: $10.35765 /$ pk.2020.2902.20

\title{
W cieniu orlich skrzydeł. Złożona symbolika orła na przykładzie wybranych godeł krakowskich kamienic
}

\section{STRESZCZENIE}

$\mathrm{W}$ artykule przedstawiono najbardziej istotne $\mathrm{i}$ oryginalne $\mathrm{z}$ punktu widzenia analizy symbolicznej możliwości interpretacji przedstawień białego i czarnego orła, obecnych w godłach trzech wybranych kamienic starego Krakowa. We wstępie wyjaśniono istotę symbolu, zróżnicowanie jego recepcji w różnych kręgach kulturowych oraz ambiwalentny charakter i wynikające z niego szerokie możliwości interpretacyjne. Główna część tekstu prezentuje liczne sposoby odczytania symboliki białego i czarnego orła w literaturze, historii, tradycji i sztuce pogańskiej oraz chrześcijańskiej, polskiej i międzynarodowej, skupiając się następnie na analizie lokalnych, krakowskich przedstawień orłów, do których proponowane treści mogą mieć zastosowanie.

SŁOWA KLUCZE: symbolika, orzeł, Kraków, kamienice, godło

\section{ABSTRACT}

In the Shadow of the Eagle's Wings. The Complex Symbolism of the Eagle on the Example of the Selected Emblems of Old Town Houses in Krakow

The article presents the most substantial and original ways of the symbolic interpretation of white and black eagles in the selected emblems of three old town houses in Krakow. The preface presents the essence of the symbol, its different receptions in various cultures and its ambivalent character which leads to numerous ways of interpretation. The main part of the text discusses the wide possibilities of deciphering the symbolic meaning of white and black eagles in literature, history, tradition and pagan or Cristian art, be it Polish or international, focusing on the analysis of local, Krakow representations of eagles to which some of the proposed meanings can be attributed.

KEYWORD S : symbolism, eagle, Krakow, town houses, emblem 
Ze względu na swą pojemność i bogactwo znaczeń symbole zagościły na stałe w ludzkiej świadomości, w naszej metodzie rozumienia świata i odnajdywania jego nie zawsze jasnych treści. Pomagają wyrazić czytelnie, choć bez słów, to co niewymierne, ukryte, są uosobieniem naszych lęków, pragnień, wierzeń, a ponieważ ich korzenie dotykają najgłębszej ludzkiej przeszłości i tradycji, łatwo przemawiają do każdego, kto ma odwagę podjąć próbę ich odczytania. Do najstarszych symboli, obok prostych figur geometrycznych, należą barwy, części ludzkiego ciała, rośliny i zwierzęta, zatem to wszystko, z czym człowiek stykał się bezpośrednio już w najdawniejszych czasach i co pomagało mu opisać rzeczywistość i własne emocje, zanim jeszcze powstało pismo. Pierwotny, nierozerwalny związek człowieka z naturą wpłynął i nadal wpływa na kształtowanie mnóstwa symboli, które otaczają nas zewsząd, w każdym wieku, w każdej części świata. Wiele nieskomplikowanych symboli zatraca jednak z biegiem czasu swój rozbudowany charakter, ponieważ tak mocno upowszechniają się w naszej rzeczywistości, że stają się zwykłymi znakami, pozbawionymi możliwości wielopoziomowej interpretacji. Nie zastanawiamy się już nad ich pochodzeniem i znaczeniem, traktując jedynie jako ułatwiający codzienne funkcjonowanie element otaczającego nas świata. Więcej autonomii zachowały i zachowują natomiast symboliczne przedstawienia dekoracyjne, rozpowszechnione zwłaszcza w sztuce użytkowej, malarstwie i architekturze, wśród których niesłabnącą popularnością cieszą się wyobrażenia realnie istniejących lub mitycznych zwierząt. Każda społeczność posiada zazwyczaj cenne z uwagi na swą odrębną historię, położenie geograficzne i tradycje symbole zoomorficzne, które umieszczane są w przestrzeni indywidualnej i wspólnej jako wyraz przywiązania do określonych wartości, estetyki miejsca czy aspiracji przebywających w tych przestrzeniach osób. Tego rodzaju symbole (głównie dekoracje architektoniczne, zoomorficzne kształty przedmiotów kultu lub elementów ozdobnych, godła budynków itp.) stawiają już przed kulturoznawcami i badaczami tradycji lokalnych konkretne trudności interpretacyjne, jako że prawidłowa bądź dopuszczalna interpretacja danego przedstawienia wymaga nierzadko szerokiej znajomości nie tylko historii i tradycji lokalnej, lecz także kultur, religii czy piśmiennictwa przekraczających granice jednego, historycznego miejsca, obszaru czy narodu. Jedno tylko symboliczne zwierzę może posiadać bowiem w różnych kontekstach kulturowych i historycznych zróżnicowane znaczenia i konotacje, pozytywne lub negatywne, co zresztą potwierdza immanentną cechę każdego symbolu, jaką jest ambiwalencja, wielość znaczeń. Istotne znaczenie dla interpretacji lokalnej symboliki określonego przedstawienia zoomorficznego ma też czynnik czysto ludzki, często niepoddający się logicznym zasadom rozumowania, a zatem wymagający indywidualnej, 
specyficznej analizy, w której niezbędna okazuje się zazwyczaj znajomość historii miejscowej budynku czy historii rodzinnej właściciela lub fundatora.

W polskim, narodowym kręgu kulturowym szeroko rozpowszechnionym i cieszącym się powszechną estymą symbolem zoomorficznym jest orzeł. Przedstawiany zwłaszcza w królewskiej pozie, z rozpostartymi szeroko skrzydłami, głęboko wrósł w polską świadomość narodową i z tego względu stanowi jeden z częściej stosowanych motywów dekoracyjnych w godłach kamienic historycznych miast. Jako że bliski kulturze polskiej, orzeł biały ma swoje wyraźne przeciwieństwo w orle czarnym, również szeroko rozpowszechnionym jako symbol, jednak w innych kręgach kulturowych, w niniejszym artykule skupimy się na analizie porównawczej tych dwóch rozbudowanych symboli, omawiając możliwe znaczenia i interpretacje na przykładzie kilku przedstawień białego i czarnego orła, obecnych na fasadach krakowskich kamienic.

Biały orzeł, powracający do swego gniazda na wysokim dębie, pojawia się jako symbol już w opowieści o Lechu, Czechu i Rusie zapisanej około połowy XIV wieku w Kronice wielkopolskiej (Derwich, 1985). Interpretowany powszechnie jako znak otrzymany od bogów przez Lecha, legendarnego założyciela narodu Lechitów i miasta Gniezna, z biegiem czasu orzeł zaczyna funkcjonować jako polskie godło narodowe. Jednymi z pierwszych przedstawień tego ptaka w funkcji polskiego godła (znanego wszystkim orła w koronie) są pochodzące z 1290 roku pieczęcie książęce późniejszego króla Polski, Przemysła II, które władca przejął zapewne od Henryka IV Probusa wraz z planami wzmocnienia Królestwa Polskiego oraz, przypuszczalnie, z aspiracjami koronacyjnymi (Nikodem, 2005). Obecnie symbol białego, narodowego orła upowszechnił się na tyle, że znaleźć go możemy praktycznie wszędzie: orzełki noszą na swoich mundurach polscy żołnierze, orzeł figuruje tė̇ na rewersach monet, znaczkach i polskich pieczęciach urzędowych (Grębecka, 2017). Na ulicach Krakowa, na fasadach historycznych kamienic również pojawia się prosty lub stylizowany wizerunek białego orła, a jedne z najlepiej znanych krakowianom przedstawień królewskiego ptaka znajdują się w samym sercu starego Krakowa: na północnej fasadzie Bramy Floriańskiej - to orzeł piastowski z 2. poł. XIX wieku, projektu Jana Matejki, oraz na kamienicy przy ul. Floriańskiej 42, czyli dawnym hotelu „Pod Białym Orłem”, dziś części Hotelu Polskiego. Godło dawnego hotelu pochodzi z pamiętnego roku 1815 (Rożek, 2008), czyli z okresu upadku Napoleona, gdy z jednej strony nikły polskie marzenia o odzyskaniu niepodległości, z drugiej zaś rosły nadzieje, gdy kongres wiedeński tworzył Wolne Miasto Kraków (kontrolowane wprawdzie przez zaborców, ale cieszące się względną autonomią, opartą na własnej konstytucji). 


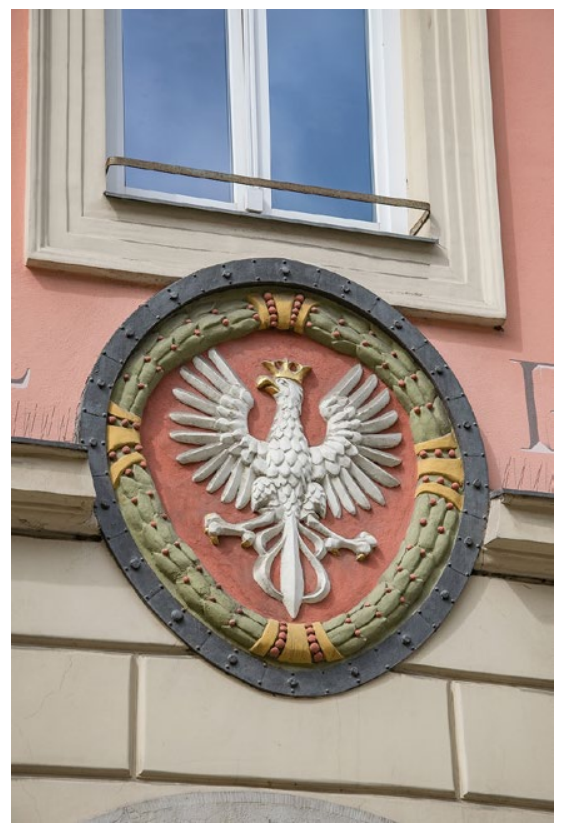

Zdjęcie 1. Orzeł z fasady Hotelu „Pod Białym Orłem”. Zdjęcie autorskie

W 1827 roku Franciszek Staniszewski założył przy ul. Floriańskiej 42 niedrogi zajazd, od 1858 roku zwany powszechnie hotelem „Pod Białym Orłem”, w którym zatrzymywali się zazwyczaj mało znani i niewymagający goście. Gwarantujący swoistą anonimowość hotel upodobali sobie zatem działacze polskiego podziemia i konspiratorzy, którzy w czasach zaborów znaleźli tam bezpieczną przystań. Czy zawsze jednak bezpieczną? Historia wspomina o licznych aresztowaniach działaczy polskiego ruchu oporu, które miały miejsce w murach hotelu: w 1878 roku aresztowano tam Ludwika Waryńskiego, a podczas II wojny światowej Wandę Krahelską, której twarz możemy po dziś dzień rozpoznać w rysach warszawskiej Syrenki. Dawny hotel „Pod Białym Orłem” posiada zatem historię równie bogatą, jak symbolika jego arystokratycznego godła. Co jednak symbolizuje orzeł, w jaki sposób należy interpretować zarówno jego ogólną wymowę, jak i znaczenie lokalne?

Geneza symbolu orła sięga już kultury ludów praindoeuropejskich, dla których orzeł uosabiał Diausa, boga wszechrzeczy, najwyższego stwórcę i opiekuna jasnego dnia (Maczkowski, 2002). Grecki filozof Arystoteles widział w orle uosobienie poznania i duchowej kontemplacji, a dla starożytnych Rzymian orzeł był atrybutem najwyższego z bogów, Jupitera. Za swoje godło przyjmowali orła niemal wszyscy znaczni wodzowie: rzymscy cesarze, Karol Wielki, Napoleon Bonaparte, a wszystkowidzący orzeł 
o dwóch głowach stanowił przez wieki symbol Cesarstwa Bizantyjskiego i Świętego Cesarstwa Rzymskiego Narodu Niemieckiego (Panfil, 2001).

W ikonografii chrześcijańskiej orzeł pojawia się w 1. poł. IV wieku n.e., w tzw. epoce pokonstantyńskiej, co wynika z silnego umocowania wizerunku orła w rzymskim kulcie cesarzy (Forstner, 1990). Do interesujących przedstawień należy w tym kontekście orzeł jako jedna z czterech istot żyjących, homoidów z wizji proroka Ezechiela (Ez 1,4-28) oraz czterech zoomorfów z wizji św. Jana, autora Apokalipsy (Ap 4), obrazowanych za pomocą czterech oblicz widocznych wokół Bożego tronu: lwa, wołu, człowieka i orła. Oprócz skojarzeń z symbolicznymi istotami przypisanymi odpowiednio czterem ewangelistom, niektórzy autorzy chrześcijańscy i badacze symboli widzą w tych wizjach nawiązanie do czterech żywiołów lub elementów kosmosu: lew oznacza zatem ogień, wół - ziemię, człowiek - ludzkość, a orzeł - powietrze (Wojciechowska, 2009). Orzeł lata wysoko, króluje na wyżynach świata, jest więc, jak zauważa w swym artykule Joanna Zagożdżon-Łyszczarz „królem ptaków i ptakiem królów” (2018, s. 115).

Powyższe przedstawienia, a wraz z nimi symbol orła, można też interpretować abstrakcyjnie jako metafory siły, potęgi, odwagi i władzy królewskiej. Oprócz typowych dla ikonografii chrześcijańskiej przedstawień orła u boku św. Jana Ewangelisty (takie godło istnieje również w Krakowie, na fasadzie domu przy ul. Sławkowskiej), warto wspomnieć również orła jako atrybut św. Jana Chrzciciela, św. Augustyna i św. Jana od Krzyża (z piórem w dziobie). W krakowskiej tradycji lokalnej pojawiają się ponadto cztery majestatyczne orły strzegące, wg średniowiecznej legendy, ciała zamordowanego z rozkazu króla Bolesława Śmiałego bpa Stanisława ze Szczepanowa.

Orzeł to zatem królewskość, władza, słońce i ogień, grom i piorun, dobra wróżba, ochrona, siła i zwycięstwo. Orzeł niesie nadzieję, chwałę i nieśmiertelność, symbolizuje też wytrwałość. W swoich pismach Erazm z Rotterdamu barwnie przedstawia za rzymskim historykiem Pliniuszem Starszym próbę, jakiej orły rzekomo poddają swoje nowo narodzone pisklęta - stary orzeł każe im spoglądać prosto w słońce, a gdy któreś pisklę nie daje rady i odwraca wzrok, wtedy ojciec wyrzuca je z gniazda (1973). Świety Ambroży, doktor Kościoła i patron Mediolanu, rozwija ten motyw, nadając mu w swych kazaniach sens religijny: na Sądzie Ostatecznym Chrystus, nazywany przez Ambrożego metaforycznie „orłem, który zniżył swój lot”, w podobny sposób odrzuci niegodnych przebywania w Jego obecności. Wspomniany już powyżej Pliniusz opisuje w swojej Historia naturalis jeszcze inne, kuriozalne zachowanie orłów: oto stary orzeł, którego wzrok już osłabł, szuka na ziemi źródła, po czym wzlatuje wysoko ku słońcu. Słońce oślepia swym blaskiem jego oczy, opala pióra, a wówczas orzeł powraca na ziemię, trzykrotnie zanurza się w źródle, niemal 
natychmiast odzyskuje siły i dawną ostrość wzroku (Kobielus, 2002). Przekonanie to kontynuuje wczesnochrześcijański Physiologus, popularny wśród średniowiecznych badaczy pierwowzór bestiariuszy, który znacznie przyczynił się do rozpowszechnienia w kulturze europejskiej symbolicznych interpretacji rozmaitych roślin i zwierzą, w tym orła. W celu uzupełnienia analizy ogólnej symboliki orła należy zaznaczyć, że jako ptak aktywny w dzień, orzeł jawi się jako naturalne przeciwieństwo mroku i zła. Jest wrogiem uosabiającej świat wodny ryby i węża, które są z kolei atrybutami ziemskości i świata podziemnego. Orzeł niosący w szponach węża symbolizuje zatem, także w duchu chrześcijańskim, duchowe odrodzenie, zwycięstwo siły niebiańskiej nad złem, triumf światła nad ciemnością, wolności nad zniewoleniem (warto przypomnieć tu liczne przedstawienia orłów na średniowiecznych chrzcielnicach) (Kobielus, 2002).

Ukazane powyżej przykłady dowodzą zatem pozytywnej i budującej symboliki orła, w ikonografii najczęściej przedstawianego w białym upierzeniu. Należy jednak zauważyć, że także w pismach wybitnych teologów chrześcijańskich pojawiają się negatywne interpretacje przedstawienia orła: Klemens Aleksandryjski i papież Grzegorz Wielki uważali orła za symbol złych mocy porywających dusze, podczas gdy dominikański teo$\log$ i filozof Albert Wielki widział w orle symbol pychy i gniewu (Kobielus, 2002). Dowodzi to istotnej, immanentnej cechy każdego symbolu, jaką jest jego ambiwalencja, dwuznaczność. Nawet mocno i pozytywnie zakorzeniony w świadomości symbol może budzić, w tym samym lub innym kręgu kulturowym, mniej oczywiste czy wręcz negatywne interpretacje. Także i orzeł może więc, obok triumfu dobra i blasku zwycięstwa, symbolizować atakujące nagle zło, burzę, błyskawiczną klęskę, pożogę, żarłoczność lub śmierć głodową. Już Arystoteles twierdził bowiem, że starym orłom tak bardzo zakrzywia się dziób, że nie są w stanie przyjmować pokarmu i giną z głodu, o czym również wspomina w swej publikacji Stanisław Kobielus (2002). W tradycyjnym judaizmie orzeł uznawany jest wręcz za zwierzę nieczyste: „spośród ptaków będziecie mieli w obrzydzeniu i nie będziecie ich jedli, bo są obrzydliwością, następujące: orzeł, sęp czarny, orzeł morski, wszelkie gatunki kani i sokołów” (Kpł 11,13-14), a Księga Hioba określa orła jako zwierzę złowrogie i żarłoczne, którego „pisklęta (...) krew chłepcą, on wszędzie tam, gdzie zabici” (Hi 39,30).

Jak zatem prawidłowo zinterpretować białego orła w godle dawnego hotelu przy ul. Floriańskiej 42 w Krakowie? Z uwagi na epokę historyczną, w której godło powstało, oraz szczególnie nasilone wówczas tendencje wyzwoleńcze i narodowościowe, związane $z$ istotnym dla Polski okresem napoleońskim, uzasadniona zdaje się w tym wypadku interpretacja czysto pozytywna, o charakterze patriotycznym. Symbol białego orła stanowić mógł też wymierną zachętę oraz znak rozpoznawczy dla 
lokalnych zwolenników walki o niepodległość, których losy historia złączyła z tym zabytkowym budynkiem. W podobnym duchu należy rozpatrywać historyczną wymowę piastowskiego orła, którego w 1882 roku Jan Matejko zaprojektował nie tylko dla ozdoby starych murów Krakowa, lecz także dla podtrzymania wśród krakowian i przyjezdnych świadomości bogatej, wielowiekowej historii Polski.

Podobnie bogatym znaczeniowo, choć mniej rozpowszechnionym na polskim gruncie narodowym symbolem jest orzeł czarny. Głównie ze względu na pozytywną w kulturze europejskiej konotację barwy białej, czarnemu orłu nietrudno przypisać z kolei cechy negatywne, związane ze statusem czerni w powszechnie stosowanej na naszym kontynencie hierarchii kolorów. Tak jak elegancka, ale i złowroga, żałobna czerń stanowi widoczne przeciwieństwo świetlistej, wolnej i czystej bieli, tak samo czarny orzeł kojarzony jest głównie z drapieżną siłą, autorytarnymi rządami twardej ręki, a w Polsce najczęściej z nieszczęśliwym dla kraju okresem rozbiorów. Czarny orzeł zdobił flagę Królestwa Prus, godło Cesarstwa Niemieckiego, czarny dwugłowy orzeł, patrzący niczym rzymski Janus w przeszłość i w przyszłość, symbolizował XVIII- i XIX-wieczne Cesarstwo Rosyjskie oraz Cesarstwo Austrii, a dla pokoleń polskich konspiratorów oznaczał przede wszystkim opresję i krzywdę. W takim właśnie świetle, jako symbol pokusy i nieszczęścia, przedstawia czarnego orła Zygmunt Krasiński w Nie-Boskiej Komedii (Bartczak, 2001), a Juliusz Słowacki w swym Hymnie interpretuje symbol orła o dwóch głowach jako uosobienie zaborczej niewoli, ustępującej z nadejściem dnia i dźwięku dzwonów:

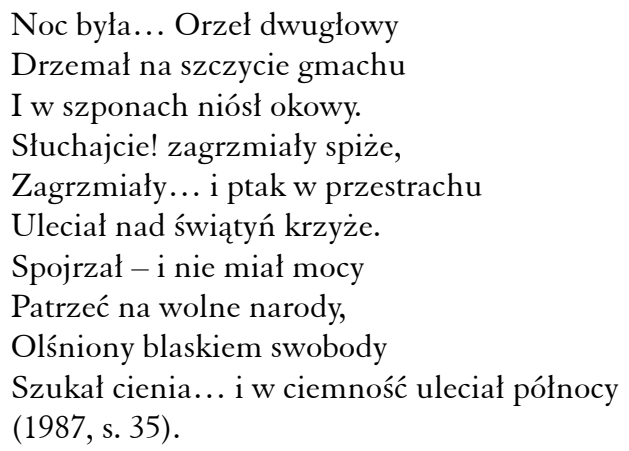

W obliczu tak często spotykanych w literaturze i sztuce negatywnych interpretacji symboliki czarnego orła należy jednak pamiętać i o tym, że jako „Płomienista Orlica” - godło czeskich Przemyślidów - czarny orzeł widniał również w herbie późniejszego króla polskiego Wacława II, a na swoich tarczach herbowych nosili go książęta z dolnośląskiej linii Piastów (czego przykładem jest np. obecność czarnego orła w dzisiejszym herbie 
Wrocławia), których działalność miała przecież niebagatelny, pozytywny wpływ na rozwój średniowiecznego Królestwa Polskiego. W polskiej heraldyce istnieje też związany z rozbudowaną symboliką czarnego orła herb Niesobia (Krzywosąd) datowany nawet na XI wiek i o interesującej genezie, którą szczegółowo przytacza i opisuje XIX-wieczny Herbarz Polski Kaspra Niesieckiego:

(...) pół strzały białej (...) w czerwonym polu pod nią ogoń orli czarny (...) Kiedy Kazimierz, król Polski, z wojskiem ciągnął, przeciwko Wratysławowi, książęciu czeskiemu, orzeł czarny nad obozem polskim latał; różni to różnie rozumiejąc, wykładali, w tym jeden znaczniejszy pułkownik, z tym się ozwał: Jeżeli, prawi, tego orła z łuku zabiję, dobry będzie znak przyszłego z nieprzyjaciół zwycięztwa, jeżeli go chybi strzała, przegrana nasza: to wymówiwszy, puścił strzałę, i orła w ogon trafił; dopiero krzyknął; Królu, wygrasz batalią tak jednak, że wielka część wojska Czeskiego pierzchnie i w rozsypkę pójdzie. Co gdy się potem tak stało, jak on powiedział, król mu w nagrodę tego dał za herb strzałę z ogonem, a że się ta potyczka nad rzeką Niesobia odprawiła, dla tego imię ztąd herbowi temu przywłaszczone (Niesiecki, 1841, s. 559).

W cytowanej powyżej legendzie czarny orzeł symbolizuje potęgę i grozę nieprzyjaciela, gdyż dopiero zabicie złowróżbnego ptaka umożliwić ma sukces wojsk Kazimierza. Niemniej jednak, ten sam postrzelony przez polskiego rycerza czarny orzeł stanowi jednocześnie pomyślną, nawet jeśli tylko połowicznie, przepowiednię: zagrzewa do walki i daje nadzieję na zwycięstwo. Ponownie zatem doświadczamy charakterystycznej dla symboli wieloznaczności, która nie pozwala poprzestać na jednotorowym, przewidywalnym sposobie interpretacji.

W środowisku krakowskim natomiast wymownym przykładem obecności symbolu czarnego orła jest XVIII-wieczny zajazd „Pod Czarnym Orłem” przy Rynku Podgórskim 13.

$\mathrm{Na}$ fasadzie budynku, zgodnie z nadaną mu nazwą, widnieje okazały czarny orzeł $\mathrm{z}$ rozpostartymi skrzydłami, niosący w dziobie winne grono. Kamienica znana jest w Krakowie głównie z faktu, że w jej murach zatrzymał się po raz ostatni przed opuszczeniem Polski Fryderyk Chopin, gdy w lipcu 1829 roku udawał się w podróż do Wiednia, by nigdy już nie powrócić do rodzinnego kraju. Zajazd „Pod Czarnym Orłem” znajduje się w krakowskiej dzielnicy Podgórze, która do 1915 roku była oddzielnym miastem, powstałym na prawym brzegu Wisły jako wytwór administracji austriackiej po pierwszym rozbiorze Polski. Niegdyś Wolne Królewskie Miasto Podgórze, podniesione do tak wysokiej rangi przez cesarza Józefa II, miało (przynajmniej formalnie) pozostać konkurencją dla nieprzychylnego nowej władzy Krakowa. Czarny orzeł w godle kamienicy jest zatem gruntownie 
umotywowany, także ze względu na fakt, że w budynku znalazł na krótko swą pierwszą siedzibę Ratusz Miasta Podgórza. Winne grono zaś przypomina zapewne o tym, że w późniejszym zajeździe „Pod Czarnym Orłem” działała winiarnia (Rożek, 2008), a w dni targowe zatrzymywali się tam przyjezdni kupcy, także z terenów Czech i Węgier.

Zdjęcie 2. Orzeł z fasady Zajazdu „Pod Czarnym Orłem”. Zdjęcie autorskie

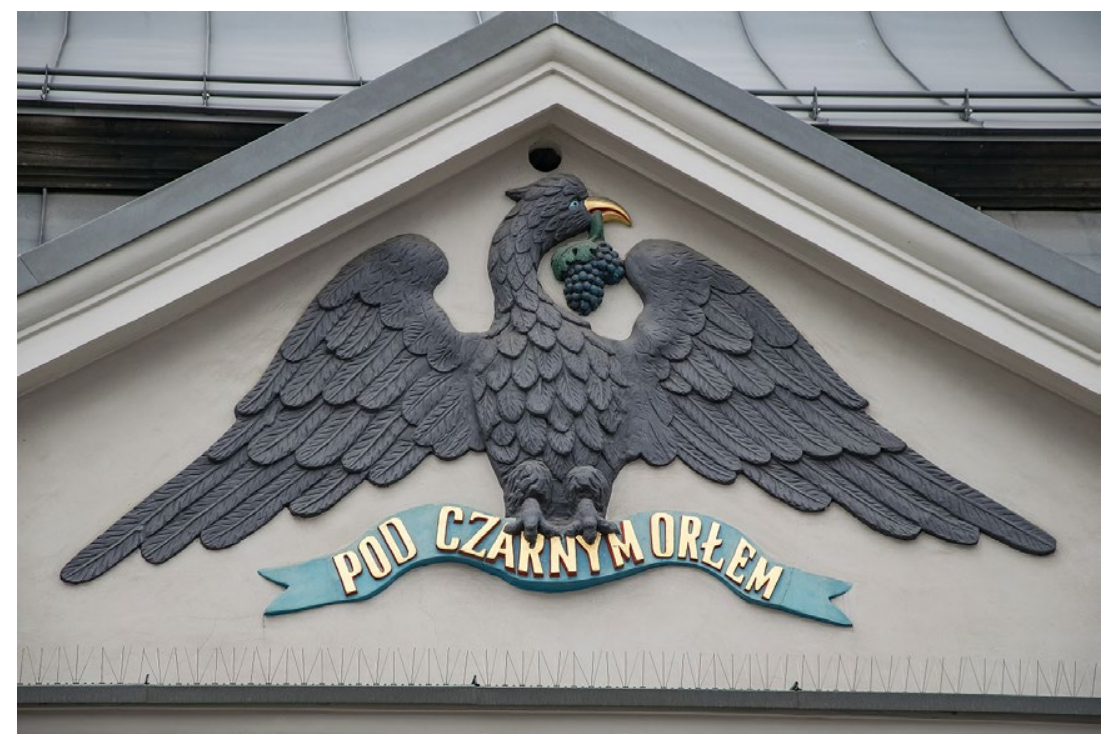

Pomimo zasadniczo czytelnej symboliki czarnego orła na fasadzie podgórskiej kamienicy, próby odczytania jej głębszego znaczenia mogą okazać się uzasadnione i prowadzić do istotnych dla lokalnego kulturoznawcy czy badacza symboli wniosków. W tym celu należy przywołać informacje historyczne dotyczące struktury narodowościowej miasta Podgórza, które jawi się jako wielokulturowe i wielonarodowościowe. Sprzyjające perspektywy rozwoju kariery oraz dogodne warunki osiedleńcze, gwarantowane uniwersałem cesarza Józefa II z lutego 1784 roku oraz przywilejem z czerwca 1785 roku, sprawiły, że w Podgórzu mieszkali i pracowali obok siebie Polacy, Żydzi, Austriacy, Niemcy, Czesi. Na terenie Podgórza prowadzili swe sklepy liczni kupcy, również krakowscy. U schyłku XVIII i w XIX wieku przybywali do Podgórza poszukujący nowych możliwości mieszkańcy innych rejonów Galicji, lecz także Czech czy Moraw, w mieście osiedlali się również wraz z rodzinami austriaccy urzędnicy i wojskowi. Możliwe zatem, że czarny orzeł nie był w tym wypadku manifestacją natury politycznej, a po prostu godłem bliskim któremuś z licznych obywateli czy mieszkańców Podgórza, który swe 
rodzinne korzenie wywodził np. z Czech. Z punktu widzenia badacza miejscowej historii interesujący może okazać się też fakt, że czarny orzeł z Rynku Podgórskiego 13 został w latach 70. XX wieku przemalowany na biało, a nazwę budynku zamieniono na „Pod Orłem” w myśl popularnej wówczas mody na intensywną polonizację i manifestowanie sympatii narodowych w przestrzeni publicznej i prywatnej ${ }^{1}$. Dopiero w 2014 roku przywrócono godłu kamienicy jego historyczną kolorystykę. Warto też przypomnieć, że nad portalem wejściowym opatrzonej kolejnym numerem kamienicy (Rynek Podgórski 14) majestatycznie prezentuje się heraldyczny stiukowy biały orzeł, a sam budynek, zwany dworkiem (zajazdem) „Pod Białym Orłem”, cieszy się również bogatą historią.

Zdjęcie 3. Orzeł z fasady dworku „Pod Białym Orłem”. Zdjęcie autorskie

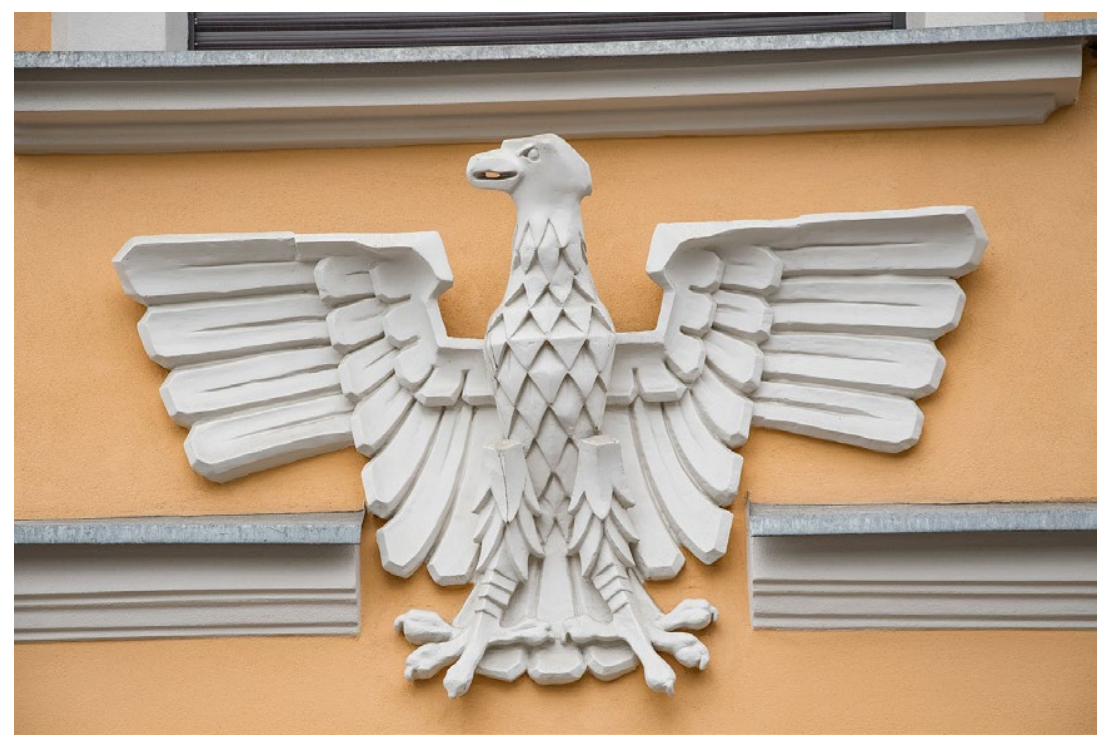

Od początku XIX wieku do ok. 1851 roku w kamienicy tej mieścił się tzw. Stary Ratusz podgórski, przeniesiony z sąsiedniego zajazdu „Pod Czarnym Orłem”. Kilkakrotnie przebudowywany, neoklasycystyczny budynek, ozdobiony godłem białego orła, stanowi zatem i kolorystyczną, i symboliczną przeciwwagę dla orła czarnego, co pozwala przywołać w tym miejscu złożoną historię samego Podgórza. Autonomiczne, nowoczesne, lecz wskutek licznych burz dziejowych wciąż zmieniające swą przynależność

1 Informacje o budynku wraz z opisem dostępne w katalogu obiektów zabytkowych Instytutu Dziedzictwa Narodowego: https://zabytek.pl/pl/obiekty/krakow-zajazd-pod-czarnym-orlem (dostęp: 20.01.2020). 
państwową, na początku XX wieku Podgórze trwale połączyło się z Krakowem. 4 lipca 1915 roku ostatni prezydent Podgórza Franciszek Maryewski i prezydent Krakowa Juliusz Leo spotkali się na moście Krakusa, podaniem sobie rąk łącząc dwa miasta na dwóch brzegach Wisły. Tendencje niepodległościowe, zmierzające do uwolnienia Krakowa od zaborców, stawały się z biegiem lat coraz silniejsze, osiagając kulminację w dniu 31 października 1918 roku, kiedy właśnie w historycznym Podgórzu por. Antoni Stawarz z austriackiego 57. Pułku Piechoty dokonał spektakularnego rozbrojenia koszarów, rozpoczynając tym samym proces wyzwalania Krakowa spod władzy austriackiej (Nowak, 2017). Wydarzenia te pozwalają twierdzić, że w środowisku krakowskim początku XX wieku siła oddziaływania niepodległościowej symboliki białego orła odniosła historycznie trwalszy efekt niż zarządzenia administracyjne i podziały zapoczątkowane czasami zaborów. Czarny zaś orzeł, umieszczony na fasadzie dawnego podgórskiego ratusza, może stanowić przypomnienie, że mimo formalnie austriackiego rodowodu miasta, jego mieszkańcy nie porzucili krakowskich sympatii i bliżej im było do Polski niż do Wiednia i Najjaśniejszego Pana.

Na zakończenie niniejszych rozważań warto jeszcze przypomnieć, że zoomorficzne godła krakowskich kamienic stanowią bogate źródło inspiracji dla badaczy współczesnej i dawnej symboliki przedstawień natury, ich znaczenia kulturowego i sensu historycznego. Oprócz omówionych w niniejszym tekście godeł przedstawiających orły, w centrum Krakowa można wskazać też inne wybitne przykłady podobnych realizacji, jak dom „Pod Pająkiem”, „Pod Osłem” czy pod „Śpiewającą Żabą”, projektu zasłużonego dla miasta architekta Teodora Talowskiego. W każdym z tych $\mathrm{i}$ innych jeszcze godeł świadomy obserwator dostrzeże przypisywane zwierzęcym kształtom ukryte znaczenia, utwierdzając się w słusznym przekonaniu, że nasz widzialny świat, jak zauważa Manfred Lurker, „zanurzony jest w innym większym, niepostrzegalnym świecie” (2017, s. 13).

\section{BiBLIOGRAFIA}

Bartczak, I. (2001). Nie-Boska Komedia - romantyczny moralitet. Acta Universitatis Lodziensis, Folia Litteraria Polonica, t. 4, 45-71.

Derwich, M. (1985). Janko z Czarnkowa a Kronika Wielkopolska. Acta Universitatis Wratislaviensis, $\mathrm{nr} 800,127-162$.

Erazm z Rotterdamu. (1973). Adagia. Wrocław: Ossolineum.

Forstner, D. (1990). Świat symboliki chrześcijańskiej. Warszawa: Instytut Wydawniczy Pax.

Grębecka, Z. (2017). Polskie Symbole Narodowe odc. 1, Z gniazda na tarcze herbowe. Mówia Wieki, nr 9, 56-59. 
Kobielus, S. (2002). Bestiarium chrześcijańskie. Warszawa: Instytut Wydawniczy Pax.

Lurker, M. (2017). Przestanie symboli $w$ mitach, kulturach $i$ religiach. Warszawa: Wydawnictwo Aletheia.

Maczkowski, A. (2002). Pojawienie się Indoeuropejczyków w Europie Środkowej w świetle nowej mitologii porównawczej. Toruń: Wydział Nauk Historycznych, Instytut Archeologii i Etnologii, Uniwersytet Mikołaja Kopernika w Toruniu.

Narodowy Instytut Dziedzictwa (2020). Zajazd pod Czarnym Ortem. Pozyskano z: https://zabytek.pl/pl/obiekty/krakow-zajazd-pod-czarnym-orlem (dostęp: 20.01.2020).

Niesiecki, K. (1841). Herbarz Polski Kaspra Niesieckiego S.J. powiększony dodatkami pózniejszych autorów, rękopismów, dowodów urzędowych i wydany przez Jana Nep. Bobrowicza. T. 6. Lipsk: Breitkopf i Haertel.

Nikodem, J. (2005). Kontrowersje wokół przygotowań do koronacji Przemysła II. Kwartalnik Historyczny, r. CXII/3, 111-134.

Nowak, J.T. (2017). Wyzwolenie Krakowa 31 października 1918 r. W: M. Jabłoński (red.), Rola Krakowa w odzyskaniu niepodlegtości. Kraków: Małopolskie Centrum Edukacji.

Panfil, T. Orzeł na denarze Bolesława Chrobrego - pochodzenie i znaczenie symbolu. Biuletyn Numizmatyczny. Pozyskano z: https://eps.gda.pl/ ptn/10.html (dostęp: 30.01.2020).

Rożek, M. (2008). Urbs celeberrima. Przewodnik po zabytkach Krakowa. Kraków: Wydawnictwo WAM.

Słowacki, J. (1987). Dzieła wybrane. T. 1. Wrocław: Ossolineum.

Wojciechowska, K. (2009). Typologiczna i metaforyczna symbolika czterech homoidów z czterema obliczami z Księgi Ezechiela 1,5-15.19-25 i czterech zoomorfów z Apokalipsy 4,6-8. Rocznik Teologiczny, z. 1-2 (38), 21-43.

Zagożdżon-Łyszczarz, J. (2018). Encyklopedyczna wykładnia symboliki orła w twórczości Mikołaja Reja i Marcina Bielskiego. Bibliotekarz Podlaski, nr 4, 113-145.

Karolina Janeczko - absolwentka Wydziału Filologicznego Uniwersytetu Jagiellońskiego, studiów podyplomowych Wyższej Szkoły Europejskiej im. Ks. Józefa Tischnera oraz Uniwersytetu Papieskiego Jana Pawła II w Krakowie. Doktorantka Wydziału Historii i Dziedzictwa Kulturowego Uniwersytetu Papieskiego Jana Pawła II w Krakowie. Wykładowca akademicki, tłumacz j. włoskiego, przewodnik miejski po Krakowie. 